\title{
ŚRODKI OCHRONY \\ NIEMATERIALNEGO DZIEDZICTWA KULTURY W CHIŃSKIEJ REPUBLICE LUDOWEJ
}

Dziedzictwo kultury stanowi cywilizacyjny dorobek ludzkości, na który składają się rzeczy ruchome i nieruchome wraz z towarzyszącymi im wartościami duchowymi, emocjonalnymi, historycznymi, religijnymi czy artystycznymi, istotnymi dla danego społeczeństwa i przekazywanymi przez nie z pokolenia na pokolenie ${ }^{1}$. Obiekty tworzące dziedzictwo kultury możemy podzielić na materialne i niematerialne. Do materialnego dziedzictwa kultury możemy zaliczyć wszelkiego rodzaju budynki, zabytki, książki, dzieła sztuki, dokumenty, a nawet historyczne stroje, będące przejawem namacalnej, kulturowej twórczości człowieka. Z kolei na niematerialne dziedzictwo kultury składają się tradycje, zwyczaje i praktyki oraz różnego rodzaju językowe i artystyczne ekspresje. W celu zapewnienia trwałości i ciagłości całego światowego niematerialnego dziedzictwa kultury powstały liczne regulacje prawne gwarantujące mu ochronę, których zwieńczeniem jest Konwencja UNESCO w sprawie ochrony niematerialnego dziedzictwa kulturowego, sporządzona w Paryżu dnia 17 października 2003 r. (Dz. U. z 2011 r. Nr 172, poz. 1018). Konwencja ta nakłada na państwa-strony liczne obowiązki, w tym obowiązek sporządzenia rejestrów niematerialnego dziedzictwa kultury, wprowadzenia ustawodawstwa krajowego, które zapewni środki ich identyfikacji i utrwalenia, a także opracowania planów ich wykorzystywania i dalszego rozwoju, w zależności od ich charakteru.

Chińska Republika Ludowa ze względu na długą i niepowtarzalną historię oraz rozpiętość geograficzną ma niezwykle bogate dziedzictwo kultury. Co więcej, silna świadomość tożsamości narodowej Chińczyków i pielęgnowanie przez nich tradycji wpłynęły na ukształtowanie się w Chinach unikatowego zasobu niematerialnego dziedzictwa kultury. Niezaprzeczalne jest jednak, że postępująca globalizacja i dynamika wprowadzania nowych technologii oraz prężny rozwój gospodarczy Chin przyczyniają się do zaniku kultury tradycyjnej tego państwa. W dobie zagrożenia tradycji niematerialne dziedzictwo kultury Chin zasługuje na wzmożoną ochronę prawną nie tylko na poziomie międzynarodowym, ale przede wszystkim na poziomie krajowym, czego owocem jest specjalna ustawa - Prawo Chińskiej Republiki

ORCID: 0000-0002-4157-6853, DOI: 10.4467/23538724GS.20.027.12145

1 J. Pruszyński, Džiedzৃictwo kultury Polski: jego straty i ochrona prawna, t. 1, Kraków 2011, s. 50. 
Ludowej o niematerialnym dziedzictwie kultury, a także na propagowanie w społeczeństwie potrzeby i wagi kultywowania kultury tradycyjnej. Celem niniejszego artykułu jest przedstawienie środków ochrony dziedzictwa niematerialnego w Państwie Środka i form ich realizacji.

\section{Pojęcie niematerialnego dziedzictwa kultury i jego ochrona na szczeblu międzynarodowym}

Aby zdefiniować „niematerialne dziedzictwo kultury”, niezbędne jest przede wszystkim odniesienie się do samego terminu „dziedzictwa kultury” - szerokiego i jak się okazuje dość problematycznego. „Dziedzictwo kultury” jest pojęciem dynamicznym i trudnym do zdefiniowania, gdyż jego zakres nie jest jednolicie ustalony i jednoznacznie postrzegany. Dzieje się tak przede wszystkim dlatego, że trudno znaleźć jedną definicję pojęcia „kultura”, która w swoich ramach ujęłaby wszystkie możliwe i wciąż rozwijające się płaszczyzny tego zjawiska. Najogólniej kulturę można uznać za całokształt duchowego i materialnego dorobku ludzkości, który został wytworzony na kolejnych etapach rozwoju historycznego i jest nieustannie utrwalany oraz wzbogacany ${ }^{2}$. Patrząc szerzej, pojęcie „kultura” może być rozważane w ujęciu temporalnym (zestawione $\mathrm{z}$ daną epoką tworzy np. kulturę antyczną czy kulturę renesansowa, a nacisk zostaje położony na przekazywanie dziedzictwa kultury), ujęciu twórczym (jako przejaw kreatywnej twórczości człowieka), ujęciu normatywnym (określone wzory postępowań i styl życia), a także w ujęciu psychologicznym (proces uczenia się i wytwarzania nawyków) oraz duchowym (umysłowa aktywność człowieka i tworzony przez niego system wartości) $)^{3}$.

Obecnie przyjęto, że kultura składa się dwóch głównych komponentów, tj. kultury materialnej i niematerialnej. Kulturę materialną stanowią namacalne, konkretne wytwory danego społeczeństwa, często pokrywające się z dorobkiem cywilizacyjnym danej grupy. Na kulturę niematerialną będą się z kolei składać wszelkiego rodzaju duchowe wytwory społeczeństwa, takie jak wierzenia, przekonania, wartości, zwyczaje, prawa, znaki, symbole czy język, które mają charakter abstrakcyjny i aby przetrwać, muszą zostać utrwalone. Gdy do kultury dodamy element pokoleniowości, będziemy mieć do czynienia z dziedzictwem kultury będącym świadectwem osiagnięć człowieka (materialnych i niematerialnych), które ze względu na swoją wartość są uznawane za ważne 5 .

2 Stownik wspótczesnego jezyyka polskiego, t. 1, red. B. Dunaj, Warszawa 2001, s. 440, 441.

3 W. Daszkiewicz, Podstawowe rozumienie kultury - ujecie filozoficzne, „Roczniki Kulturoznawcze” 2010, t. 1 , s. 49.

4 M. Gruchoła, Kultura w ujeciu socjologicznym, „Roczniki Kulturoznawcze” 2010, t. 1, s. 98.

5 K. Zeidler, Prawo ochrony dziedzictwa kultury, Warszawa 2007, s. 26, 27. 
Wspomniana wartość dziedzictwa kultury spowodowała, że społeczność międzynarodowa poczuła się za nie odpowiedzialna i poczyniła kroki do zapewnienia mu określonych standardów prawnych, a także wytworzenia specjalnego modelu ochronnego, co znalazło odzwierciedlenie w wielu dokumentach międzynarodowych. Pierwsze regulacje pojawiły się już w 1945 r., w Konwencji dotyczącej utworzenia Organizacji Narodów Zjednoczonych dla Wychowania, Nauki i Kultury, podpisanej w Londynie dnia 16 listopada 1945 r. (Dz. U. z 1947 r. Nr 46, poz. 242). Zgodnie $z$ art. 1 pkt 1 lit. c organizacja, w celu zapewnienia pokoju i bezpieczeństwa przez pogłębianie - za pomocą wychowania, nauki i kultury - współpracy narodów, będzie przede wszystkim pielęgnowała, rozwijała i rozpowszechniała wiedzę, zapewniając ochronę i opiekę światowemu dziedzictwu książek, dzieł sztuki i pomników historii i nauki oraz będzie zachęcać narody do współpracy międzynarodowej we wszystkich dziedzinach działalności intelektualnej ${ }^{6}$.

Normatywna definicja dziedzictwu kultury po raz pierwszy pojawiła się w Konwencji UNESCO w sprawie ochrony światowego dziedzictwa kulturalnego i naturalnego, przyjętej 16 listopada 1972 r. w Paryżu (Dz. U. z 1976 r. Nr 32, poz. 190)7. $\mathrm{Na}$ mocy tej konwencji utworzono kompleksowy mechanizm ochrony dziedzictwa kulturalnego i naturalnego ${ }^{8}$. Oprócz ogólnego określenia dziedzictwa kultury wyodrębniono również jego rodzaje, dla których także przewidziano ochronę. Wśród nich możemy wyróżnić np. dziedzictwo archeologiczne, architektoniczne, podwodne i niematerialne. To ostatnie zostało szczegółowo uregulowane we wspomnianej już Konwencji UNESCO w sprawie ochrony kulturowego dziedzictwa niematerialnego z 2003 r. Istotne znaczenie dla powstania konwencji z 2003 r. miały trzy dokumenty: Zalecenie w sprawie ochrony tradycyjnej kultury i folkloru z 15 listopada 1989 r. (dalej: Zalecenie z 1989 r.), Powszechna deklaracja UNESCO w sprawie różnorodności kulturalnej z 2 listopada 2001 r. oraz Deklaracja z Istambułu z 17 września 2002 r. ${ }^{9}$

6 E. Charymska, Mięzynarodowy wymiar dżiedzictwa kulturalnego, „Acta Scientifica Academiae Ostrovienis, Sectio A: Nauki Humanistyczne, Społeczne i Techniczne” 2016, nr 7(1), s. 177.

7 Zgodnie z art. 1 konwencji za dziedzictwo kulturalne uważa się: a) zabytki, czyli dzieła architektury, dzieła monumentalnej rzeźby i malarstwa, elementy i budowle o charakterze archeologicznym, napisy, groty i zgrupowania tych elementów, mające wyjątkową powszechną wartość z punktu widzenia historii, sztuki lub nauki, b) zespoły: budowli oddzielnych lub łącznych, które ze względu na swą architekturę, jednolitość lub zespolenie z krajobrazem mają wyjątkowa powszechną wartość z punktu widzenia historii, sztuki lub nauki, c) miejsca zabytkowe: dzieła człowieka lub wspólne dzieła człowieka i przyrody, jak również strefy, a także stanowiska archeologiczne, mające wyjątkową powszechną wartość z punktu widzenia historycznego, estetycznego, etnologicznego lub antropologicznego.

8 M. Marcinkowska, Chiny na Liście Dziedzictwa Światowego UNESCO [w:] Chiny w oczach Polaków. Ksiega Jubileuszowa z okazji 60-lecia nawiazania stosunków dyplomatycznych mięryy Polska a Chinska Republike Ludowa, red. J. Włodarski, K. Zeidler, M. Burdelski, Gdańsk 2010, s. 227.

9 Wszystkie trzy dokumenty są dostępne w języku angielskim na stronie: http://niematerialne. nid.pl/Ochrona_dziedzictwa/Wytyczne/ (dostęp: 25.04.2020). 
We wstępie Zalecenia z 1989 r. podkreślono, że folklor stanowi element powszechnego dziedzictwa ludzkości oraz odgrywa istotną rolę w jednoczeniu różnych społeczności i grup, określając ich kulturalną tożsamość. Tradycyjne formy folkloru mają niezwykle ulotny charakter i moga łatwo ulec zapomnieniu, dlatego państwa powinny możliwie szybko podejmować działania na rzecz ich ochrony. Sam folklor, w punkcie A części B dotyczącej ochrony kultury tradycyjnej i folkloru, został zdefiniowany jako całość kreatywności wspólnoty kulturalnej, opartej na tradycji, wyrażanej przez grupy lub poszczególne jednostki oraz uznawanej za odzwierciedlenie jej oczekiwań, a także jako wyraz kulturalnej i społecznej tożsamości. Do form folkloru zalicza się: literaturę, muzykę, język, taniec, mity, obrzędy i obyczaje, rękodzieła i inne niewymienione sztuki. Jako formy możliwych działań zmierzających do zapewnienia ochrony folkloru, które powinny zostać podjęte na szczeblu krajowym, Zalecenie z 1989 r. w punktach B i C wskazuje: identyfikację folkloru poprzez jego inwentaryzację, katalogowanie i klasyfikację, tworzenie odpowiednich miejsc umożliwiających jego zachowanie (muzea, archiwa) oraz zapewnienie jego przetrwania i rozpowszechniania, w szczególności przez kształcenie i prowadzenie badań, organizowanie wystaw i festiwali oraz przygotowywanie materiałów informacyjnych i edukacyjnych.

Powszechna Deklaracja UNESCO w sprawie różnorodności kulturalnej z 2 listopada 2001 r. ma bardziej ogólny charakter niż ustalenia zawarte w Zaleceniu z 1989 r. ${ }^{10}$ Przede wszystkim zwrócono w niej uwagę, że różnorodność kulturalna powinna być traktowana jako wspólne dziedzictwo ludzkości, dlatego należy jej zapewnić ochronę dla dobra obecnych i przyszłych pokoleń ${ }^{11}$. Jak wskazano w art. 7, dziedzictwo kultury powinno być zachowywane, wzbogacane i przekazywane przyszłym pokoleniom jako świadectwo ludzkich doświadczeń i aspiracji oraz niewyczerpane źródło kreatywności i inspiracji.

Deklaracja z Istambułu z 17 września 2002 r. odegrała bardzo ważną rolę przy powstawaniu konwencji UNESCO z 2003 r. Przede wszystkim zwrócono w niej uwagę, że niematerialne dziedzictwo kultury „tworzy zespół żywych i nieustannie odtwarzanych zwyczajów, wiedzy i przekazów, które umożliwiaja jednostkom i wspólnotom, na różnych poziomach, wyrażanie ich idei poprzez system wartości i standardów etycznych", a także że jest ono narażone na zanikanie z powodu negatywnych skutków współczesności - urbanizacji i globalizacji12. Tym samym podkreślono szczególną rolę organizacji UNESCO w rozwijaniu ochrony niematerialnego dziedzictwa kultury.

\footnotetext{
10 A. Przyborowska-Klimczak, Międzynarodowa ocbrona niematerialnego dziedzictwa kulturalnego, „Problemy Współczesnego Prawa Międzynarodowego, Europejskiego i Porównawczego” 2014, vol. III, s. $6,7$.

11 Ibidem.

12 Ibidem, s. 9.
} 
Jak wspomniano, wszystkie trzy dokumenty stanowiły jeden z fundamentów przyjęcia 17 października 2003 r. Konwencji UNESCO w sprawie ochrony niematerialnego dziedzictwa kultury, będącej pierwszym instrumentem prawnie wiążącym, który dotyczy ochrony dziedzictwa niematerialnego. Zgodnie z art. 2 ust. 1 konwencji na niematerialne dziedzictwo kultury składają się praktyki, wyobrażenia, przekazy, wiedza i umiejętności - jak również związane z nimi instrumenty, przedmioty, artefakty i przestrzeń kulturowa - które wspólnoty, grupy i, w niektórych przypadkach, jednostki uznają za część własnego dziedzictwa kultury. Definicja niematerialnego dziedzictwa kultury zamieszczona w konwencji zawiera więc listę ogólnych elementów, które nie mają ograniczenia i mogą być przez państwo-stronę interpretowane $i$ względem tego poszerzane oraz rozwijane. Dane państwo może wobec tego wyróżnić własny system elementów, a także tworzyć kolejne podkategorie do kategorii już zaproponowanych w konwencji ${ }^{13}$. Do takich elementów należy np. japońskie karate-do, które ze względu na wymóg posiadania pewnych umiejętności (sekwencji ruchów) i wiedzy (przekazywanej uczniom przez mistrza), a także charakterystyczny dla karate strój, miejsce (dojo) i związek z daną społecznością zostało uznane za element dziedzictwa kultury Japonii ${ }^{14}$. Konwencja zwróciła również uwagę na fakt, że dziedzictwo to jest przekazywane z pokolenia na pokolenie oraz stale odtwarzane przez wspólnoty i grupy w relacji z ich otoczeniem, oddziaływaniem przyrody i ich historia, zapewniając im poczucie tożsamości i ciagłości, a tym samym przyczyniając się do wzrostu poszanowania dla różnorodności kulturowej oraz ludzkiej kreatywności. Do przejawów niematerialnego dziedzictwa kultury zaliczamy przede wszystkim zwyczaje, rytuały i obrzędy, tradycje oraz przekazy ustne (w tym również język), sztuki widowiskowe, jak również tradycyjne rzemiosło i wiedzę dotyczącą wszechświata.

Nie da się ukryć, że materialnemu dziedzictwu kultury łatwiej jest zapewnić ochronę prawna. Kwestia ochrony niematerialnego dziedzictwa kultury jest bardziej złożona, bo dla swojej efektywności i skuteczności wymaga jego utrwalenia za pomocą określonych nośników (np. książki, pamięci elektronicznej czy samego człowieka) ${ }^{15}$, dlatego też procesy utrwalania, zachowywania i przekazywania następnym pokoleniom będą się różnić w zależności od rodzaju dziedzictwa, z jakim będziemy mieć do czynienia.

Pierwszym krokiem w kierunku stworzenia mechanizmu ochrony było ustanowienie, na mocy konwencji UNESCO z 2003 r., Międzyrządowego Komitetu ds. Ochrony Niematerialnego Dziedzictwa Kulturowego. Organ ten, składający się z przedstawicieli osiemnastu państw-stron, ma za zadanie sprawować pieczę

13 M. Marcinkowska, P. Rybiński, Karate-do as intangible cultural heritage within the meaning of the 2003 UNESCO Convention [w:] Sensei Hidetaka Nishitama's Legacy. The Educational Value of Traditional Karate-do, eds. W. Kwieciński, K. Zeidler, J. Kamień, Gdańsk 2017, s. 126.

14 Ibidem. s. 127, 128.

15 K. Zeidler, Prawo ochrony dziedzictwa..., s. 29. 
nad elementami niematerialnego dziedzictwa - udziela wskazówek w zakresie najlepszych praktyk i zaleceń dotyczących środków ochrony, promuje cele konwencji oraz wspiera i monitoruje ich realizacje, analizuje sprawozdania przedstawiane przez państwa-strony, a także sporządza wytyczne operacyjne dotyczące wdrażania konwencji.

$\mathrm{Na}$ poziomie międzynarodowym ochrona niematerialnego dziedzictwa kultury jest realizowana również poprzez sporządzenie i uaktualnianie przez Komitet Listy reprezentatywnej niematerialnego dziedzictwa kulturowego ludzkości, skupiającej wybrane zjawiska z zakresu tego dziedzictwa, a także Listy niematerialnego dziedzictwa kulturowego wymagającego pilnej ochrony, na którą wpisuje się elementy zagrożone i podlegające zanikowi. Komitet okresowo wspiera wybrane narodowe, subregionalne i regionalne programy, które mają na celu zapewnienie ochrony dziedzictwa zgodnie z duchem konwencji.

Oprócz tego zostały nałożone na państwa-strony liczne obowiązki pozwalające na zapewnienie ochrony niematerialnego dziedzictwa kultury na szczeblu krajowym. Przede wszystkim państwo-strona jest zobowiązane podjąć niezbędne środki ochrony niematerialnego dziedzictwa kultury znajdującego się na jego terytorium. Takimi środkami są przede wszystkim regularnie uaktualniane rejestry zidentyfikowanych elementów dziedzictwa danego państwa. Oprócz tego ogólna polityka państwa-strony powinna uwzględniać ochronę niematerialnego dziedzictwa kultury i zmierzać do wyznaczenia mu odpowiedniej funkcji w życiu zbiorowym - tak, aby było ono uznawane, szanowane i promowane w społeczeństwie. Powinny również zostać wyznaczone organy odpowiedzialne za realizację tej ochrony, a także podjęte odpowiednie działania mające na celu rozwijanie studiów naukowych, technicznych, artystycznych i metodologii badań w tym zakresie (art. 13 konwencji UNESCO 2003 r.).

Wobec powyższego każde państwo-strona jest zobowiązane do stworzenia systemu ochrony swojego niematerialnego dziedzictwa kultury, przy jednoczesnym uwzględnieniu standardów międzynarodowych. Powinno to uczynić przede wszystkim za pomoca norm na poziomie konstytucyjnym i ustawowym, ale również poprzez rozpowszechnianie i promowanie kultury w społeczeństwie. Niejednokrotnie państwo może spotkać się z licznymi trudnościami, które spowalniają lub uniemożliwiaja efektywność podejmowanych środków ochronnych. Taka sytuacja ma obecnie miejsce w Chinach, które są członkiem UNESCO od 4 listopada 1946 r. ${ }^{16}$ Obecnie bogaty dorobek kultury chińskiej odgrywa jedną z najważniejszych ról w światowym dziedzictwie kultury, jednak z racji postępującej globalizacji niematerialna część tego dziedzictwa jest narażona na zapomnienie, w związku z czym pożądane jest podjęcie dodatkowych środków ochrony.

16 M. Marcinkowska, Chiny na Liście Dziedzictwa..., s. 227. 


\section{Niematerialne dziedzictwo kultury Chin jako czesść światowego niematerialnego dziedzictwa UNESCO}

Chiny w ciagu 5 tys. lat swojej historii zgromadziły niezwykle bogate i różnorodne w skali światowej dziedzictwo kultury. Cywilizacja chińska zalicza się do najstarszych na świecie i jest jednocześnie jedyna, która przetrwała do współczesności w stanie praktycznie niezmienionym. Zawdzięcza to przede wszystkim mocno zakorzenionej tradycji i trwałemu przywiązaniu Chińczyków do swojej kultury, która niewatpliwie stanowi ważny element ich tożsamości i była fundamentem w tworzeniu ich silnej struktury państwowej.

Już w starożytności Państwo Środka osiagnęło wysoki poziom rozwoju, czego owocem były narodziny druku, ruchomej czcionki, papieru czy prochu strzelniczego, a także powstanie skutecznego systemu diagnozowania i leczenia chorób ${ }^{17}$. Wiele tych technik i praktyk stosowanych jest do dziś, co w połączeniu z różnymi obrzędami i formami artystycznymi tworzy chińskie niematerialne dziedzictwo kultury. Charakteryzuje się ono dużą różnorodnością i ze względu na wspomniane przywiązanie chińskiej ludności do tradycji wiele dziedzin życia codziennego jest w dalszym ciagu praktykowanych przez mniejszości kulturowe i etniczne. Dlatego tak ważne było włączenie tych elementów do światowego niematerialnego dziedzictwa kultury, aby z jednej strony propagować i rozpowszechniać chińską tradycje na całym globie, z drugiej zaś zapewnić jej należytą ochronę. Dzięki temu takie elementy, jak chińska kaligrafia, obchody Chińskiego Nowego Roku, czy hodowla jedwabników i produkcja jedwabiu, stanowią poniekąd symbole Chin - są znane na całym świecie i praktykowane także przez społeczeństwa innych krajów.

Chiny stały się sygnatariuszem Konwencji UNESCO w sprawie niematerialnego dziedzictwa kulturowego 2 grudnia 2004 r., tym samym wnosząc bogactwo swojej kultury w struktury UNESCO i otwierając sobie drogę do korzystania ze środków ochrony, jakie oferuje ta organizacja, w tym m.in. do ubiegania się o wpis na Listę reprezentatywną niematerialnego dziedzictwa kulturowego czy wsparcie w realizacji rządowych i społecznych programów mających na celu ochronę i propagowanie tradycji czy też uzyskanie wpisu w Rejestrze dobrych praktyk w zakresie ochrony niematerialnego dziedzictwa kulturowego (tzw. Rejestr dobrych praktyk UNESCO) ${ }^{18}$. Należy podkreślić, że Chiny zgromadziły ogromną liczbę elementów, które możemy znaleźć we wszystkich trzech wspomnianych spisach.

17 P. Ratkowska, T. Jędrysiak, Arcydžieła niematerialnego dzৃiedzictwa kulturowego Chin [w:] Džiedzictwo kulturowe regionów swiata i jego znaczenie w turystyce, red. E. Puchnarewicz, Warszawa 2011, s. 324.

18 Rejestr dobrych praktyk w zakresie ochrony niematerialnego dziedzictwa kulturowego, https://www.unesco.pl/kultura/dziedzictwo-kulturowe/dziedzictwo-niematerialne/listy-dziedzictwa-niematerialnego/621/ (dostęp: 25.04.2020). 
Do Rejestru dobrych praktyk UNESCO wpisywane są najlepsze praktyki mające na celu ochronę dziedzictwa niematerialnego, które jednocześnie najlepiej odzwierciedlają zasady i cele konwencji. Rejestr ten ma charakter informacyjny, stanowiąc źródło wiedzy o programach i projektach prowadzonych na terenie danego państwa, będącego stroną konwencji. Obecnie Chiny posiadają jedną pozycję w Rejestrze, jaką jest Strategia kształcenia następnych pokoleń wykonawców sztuki lalkarskiej ${ }^{19}$, wpisana w 2012 r. Lalkarze z prowincji Fujian w południowo-wschodniej części Chin opracowali charakterystyczną sztukę sceniczna, wykonywaną za pomocą marionetek i kukiełek. Tradycja ta wykształciła cały zespół typowych technik interpretatorskich i technik wykonywania lalek, a także towarzyszący temu repertuar i muzykę. W związku ze zmniejszeniem się liczby młodych adeptów sztuki lalkarskiej, co w dużym stopniu jest podyktowane zmianami społeczno-ekonomicznymi oraz długim okresem nauki potrzebnym do opanowania technik lalkarstwa, postanowiono sformułować specjalną strategię, która umożliwi przetrwanie tej praktyki. Celem Strategii kształcenia następnych pokoleń wykonawców sztuki lalkarskiej jest przede wszystkim ochrona procesu powstawania lalek przez organizowanie profesjonalnych szkoleń, staranne przygotowywanie materiałów dydaktycznych, organizowanie wystaw prezentujących najwybitniejsze prace z zakresu lalkarstwa Fujian oraz udostępnianie miejsc, które mogą służyć jako sale koncertowe ${ }^{20}$. Efektem Strategii jest wyszkolenie do tej pory ponad dwustu osób, które zawodowo zajęły się lalkarstwem.

Z kolei Lista reprezentatywna niematerialnego dziedzictwa kulturowego ludzko-

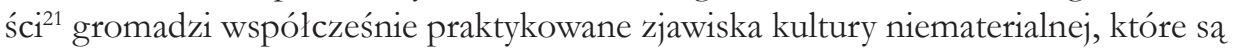
przekazywane z pokolenia na pokolenie, w celu ich wyróżnienia na arenie światowej. Jeżeli dane elementy dodatkowo są zagrożone zanikiem oraz wymagaja podjęcia specjalnych i natychmiastowych środków ochrony, to mogą zostać wpisane na Listę niematerialnego dziedzictwa kulturowego wymagającego pilnej ochrony ${ }^{22}$. Aż czterdzieści pozycji na Liście niematerialnego dziedzictwa kulturowego ludzkości dotyczy Chin (co stanowi jednocześnie najwyższy wynik wśród innych państw), a siedem z nich zakwalifikowano jako wymagające pilnej ochrony. Aby ubiegać się o szczególną ochronę danego elementu, musi on spełniać określone kryteria: 1) stanowi niematerialne dziedzictwo kultury w rozumieniu konwencji UNESCO z 2003 r.; 2) wymaga pilnej ochrony, ponieważ zagrożona jest jego żywotność, pomimo starań

\footnotetext{
19 Strategy for training coming generation of Fujian puppetry, https://ich.unesco.org/en/BSP/strategy-for-training-coming-generations-of-fujian-puppetry-practitioners-00624 (dostęp: 25.04.2020).

20 Ibidem.

21 Lista reprezentatywna niematerialnego dziedzictwa ludzkości, https://www.unesco.pl/kultura/dziedzictwo-kulturowe/dziedzictwo-niematerialne/listy-dziedzictwa-niematerialnego/listareprezentatywna-niematerialnego-dziedzictwa-ludzkosci/ (dostęp: 25.04.2020).

22 Lista dziedzictwa wymagającego pilnej ochrony, https://www.unesco.pl/kultura/dziedzictwo-kulturowe/dziedzictwo-niematerialne/listy-dziedzictwa-niematerialnego/obiekty-wymagajace-pilnej-ochrony/ (dostęp: 25.04.2020).
} 
podejmowanych przez związaną z nim grupe, wspólnotę czy pojedyncze osoby oraz państwo lub ponieważ narażony jest na poważne zagrożenia, w rezultacie których nie przetrwa, jeżeli nie zostana podjęte natychmiastowe działania ochronne; 3) zostały opracowane środki ochronne mogące pozwolić związanej z elementem wspólnocie, grupie lub pojedynczym osobom na dalsze kultywowanie i przekazywanie elementu; 4) został zgłoszony do wpisu za możliwie najszerszym udziałem związanej z nim wspólnoty, grupy czy pojedynczych osób i za ich niewymuszona, uprzednią i świadomą zgodą oraz 5) jest uwzględniony w inwentarzu niematerialnego dziedzictwa kultury znajdującego się na terytorium państwa wnioskującego ${ }^{23}$. Uzyskanie wpisu na Listę niematerialnego dziedzictwa kulturowego wymagającego pilnej ochrony sprawia, że państwo może liczyć na wsparcie UNESCO, przede wszystkim finansowe ze środków Funduszu Niematerialnego Dziedzictwa Kulturowego, ale także eksperckie i medialne.

W celu zaprezentowania różnorodności chińskiej kultury, a także różnorodności jej zagrożeń, postanowiłam wyselekcjonować trzy elementy znajdujące się na Liście niematerialnego dziedzictwa kulturowego wymagającego pilnej ochrony, które są szczególnie narażone na zanik ze względu na takie czynniki, jak migracje ludności i klęski żywiołowe, szybka urbanizacja, napływ kultury zachodniej czy deficyty surowcowe ${ }^{24}$.

Pierwszy z elementów wymagających w mojej ocenie pilnej ochrony to Festiwal Noworoczny Qiang, obchodzony pierwszego dnia dziesiątego miesiąca w kalendarzu księżycowym (czyli okres pomiędzy końcem stycznia a końcem lutego według kalendarza gregoriańskiego) przez członków grupy etnicznej Qiang z prowincji Syczuan. Chiński Nowy Rok od najdawniejszych czasów uchodzi za najważniejsze święto w tradycyjnym chińskim kalendarzu i jest jedną z największych atrakcji turystycznych Chin. Mniejszość etniczna Qiang, ze względu na lata izolacji, wytworzyła własną unikatową kulturę, której obraz najlepiej prezentują właśnie obchody z okazji Nowego Roku. Wówczas mieszkańcy prowincji przywdziewają tradycyjne, barwne stroje, śpiewaja pieśni ludowe, piją lokalne wino oraz oddają cześć bóstwom i górom, okazując tym samym szacunek swoim przodkom, ojczyźnie oraz wszystkim istotom żyjącym ${ }^{25}$. Po trzęsieniu ziemi z 2008 r., w którym uległo zniszczeniu wiele wiosek w obrębie prowincji Syczuan, UNESCO postanowiło objąć Festiwal

${ }^{23}$ Kryteria wpisu na Listę niematerialnego dziedzictwa kulturowego wymagającego pilnej ochrony, https://www.nid.pl/pl/Dla_wlascicieli_i_zarzadcow/opieka-nad-zabytkami/niematerialne-dziedzictwo-kulturowe-unesco/kryteria-wpisu-na-list-niematerialnego-dziedzictwakulturowego-wymagaj-cego-pilnej-ochrony/ (dostęp: 25.04.2020).

24 Wszystkie przedstawione elementy zostały opracowane na podstawie danych z Listy niematerialnego dziedzictwa kulturowego wymagającego pilnej ochrony, https://www.unesco.pl/ kultura/dziedzictwo-kulturowe/dziedzictwo-niematerialne/listy-dziedzictwa-niematerialnego/ obiekty-wymagajace-pilnej-ochrony/ (dostęp: 25.04.2020).

25 P. Ratkowska, T. Jędrysiak, Arcydzieła niematerialnego dziedzictwa ..., s. 334. 
specjalną ochroną i podjęło starania, aby ratować pozostałości kultury ludowej mniejszości Qiang, która ze względu na rosnące migracje ludności i napływ cywilizacji zachodniej zaczęła zanikać.

Na tę listę wpisano również tradycyjne techniki włókiennicze mniejszości narodowej Li zamieszkującej Hajnan w południowej części Chin. Wypracowane wiele wieków temu techniki włókiennicze obejmują przędzenie, tkanie, farbowanie oraz haft. Kobiety z plemienia Li tworzą wzory na tkaninach, używając jedynie swojej wyobraźni i wiedzy o tradycyjnych motywach. Przędą bawełnę, korzystając z tradycyjnych ręcznych kołowrotków, tkaja na specjalnych bambusowych krosnach, do farbowania używają tylko barwników pochodzenia naturalnego, a ich jednoi dwustronne hafty prezentują szeroki wachlarz wzorów - od postaci ludzkich i zwierząt po figury geometryczne ${ }^{26}$. Stroje wychodzące $z$ rąk tych kobiet stanowia nieodzowną część plemiennych uroczystości i obrzędów. Niemniej jednak, pomimo wagi, jaka przywiązują mieszkańcy Hajnanu do tradycyjnych strojów, liczba kobiet posiadających umiejętność tkania i haftu gwałtowanie spadła. Głównym powodem jest brak zainteresowania ze strony młodych kobiet ludowymi technikami włókienniczymi, a także ich masowe migracje do większych prowincji i miast, co powoduje niedostatek osób mogących podjąc naukę technik tkackich i haftu, by kontynuować tę tradycję.

Za szczególnie zagrożoną i wymagająca pilnej ochrony została również uznana tradycja projektowania i budowy chińskim mostów łukowych, charakterystycznych dla prowincji Fujian i Zhejian oraz położonych wzdłuż południowo-wschodniego wybrzeża Chin. Mosty łukowe odgrywają istotną rolę w życiu tamtejszej społeczności - służą jako środki komunikacji oraz miejsca spotkań, organizacji lokalnych wydarzeń i modlitw. Praktyka budowania mostów łukowych wymaga wykorzystania odpowiedniego drewna i narzędzi stolarskich, a także fachowej wiedzy dotyczącej różnorodnych uwarunkowań, rozwiązań konstrukcyjnych i sposobu łączenia drewnianych elementów mostu. Wiedza ta jest przekazywana ustnie, a nauka projektowania i budowy odbywa się w ramach indywidualnej praktyki, głównie w kręgach rodzinnych, według określonych zasad. Największymi zagrożeniami dla tego elementu są niedostatek drewna jako podstawowego surowca, z którego buduje się mosty, oraz szybka urbanizacja. Na jej skutek uszczupleniu ulegają obszary, na których mógłby powstać most.

Oprócz powyższych trzech przykładów do niematerialnego dziedzictwa kultury Chin wymagającego szczególnej ochrony należą: uroczystości Meshrep (charakteryzujące się tradycyjnymi widowiskami scenicznymi, którym towarzyszy śpiew, taniec, akrobacje oraz spożywanie tradycyjnych potraw), technologia budowania wodoszczelnych przedziałów w chińskich dżonkach, opowieści Yimakan (przekazywane ustnie historyczne wydarzenia z życia społeczności Hezhen) oraz technika druku

26 Ibidem, s. 335. 
z zastosowaniem drewnianych ruchomych czcionek. Ponadto na podstawowej Liście znajdują się m.in.: opera Kun Qu (będąca najstarszą formą opery na świecie), sztuka chińskich pieczęci, chińska kaligrafia czy też epopeja o królu Gesarze (poemat epicki Tybetańczyków, Mongołów i mniejszości Tu zamieszkujących zachodnie i północne Chiny, uważany za ostatnią „żywą epopeję”). Jak można więc zauważyć, chińskie dziedzictwo niematerialne prezentuje szeroki wachlarz różnorodnej tradycji - począwszy od sztuk scenicznych, muzyki i śpiewu, poprzez literaturę i piśmiennictwo, a skończywszy na technikach tkackich, budowlanych, konstrukcyjnych czy rzemieślniczych. Wszystkie one są jednocześnie silnie związane z grupami etnicznymi je praktykującymi.

Nie da się ukryć, że tak jak wielkie jest bogactwo niematerialnego dziedzictwa kultury Chin, tak wielkie są jego zagrożenia. W efekcie wzmożonego rozwoju gospodarczego i postępującego procesu globalizacji państwo to stanęło w obliczu nowego wyzwania, jakim jest zapewnienie ochrony i przetrwania niematerialnemu dziedzictwu kultury. Nie jest to zadanie proste, ponieważ otwarcie się Chińskiej Republiki Ludowej na rynki zachodnie, czego skutkiem jest napływ kultury masowej, wywarło ogromny wpływ na młode pokolenie, które nie przywiązuje już takiej wagi do tradycji jak ich rodzice czy dziadkowie. Dlatego tak ważne było dla Chin wypracowanie ram dla mechanizmu ochrony, przede wszystkim prawnych i administracyjnych, które są obecnie stosowane i cały czas rozwijane.

\section{Rozwój i realizacja środków ochrony niematerialnego dziedzictwa kultury Chińskiej Republiki Ludowej}

O tym, że kultura tradycyjna odgrywa istotną rolę w życiu chińskiej społeczności i trzeba zapewnić jej należytą ochronę, Państwo Środka wiedziało już na długo przed pojawieniem się pierwszych konwencji UNESCO i proponowanych wytycznych co do stosowania środków ochrony. Pierwsze działania podejmowane w celu ratowania niematerialnego dziedzictwa kultury miały charakter społeczny i pojawiły się już na początku XX wieku, dlatego w mojej ocenie warto podzielić środki ochrony na te, które były inicjowane przez chińskie społeczeństwo, w tym komitety i ruchy kulturowe, oraz te o wymiarze rządowym. Te ostatnie polegały na wprowadzaniu odpowiednich regulacji prawnych realizujących międzynarodowe standardy oraz formowaniu specjalnych organów rządowych, aparatów administracyjnych i instytucji kulturalnych odpowiedzialnych za ochronę niematerialnego dziedzictwa kultury. Niemniej jednak nieuniknione jest, że obie te formy będą na siebie wzajemnie wpływać, a niekiedy ich zakresy będą się ze sobą zazębiać, bo często ruchy społeczne mają wpływ na decyzję władz, a z kolei wsparcie rządu pozwala na rozwój zaproponowanych projektów oraz owocuje licznymi nowymi inicjatywami chińskiej społeczności. 
Już w pierwszej połowie XX wieku społeczność akademicka dostrzegła postępujący kryzys kultury tradycyjnej, spowodowany napływem zachodnich wzorców kultury, więc zaczęła podejmować pierwsze kroki, aby mu zapobiec, przede wszystkim przez tworzenie zbiorów pieśni i innych utworów ludowych, inicjując tym samym swój projekt na rzecz odbudowy „,ducha narodu”27. Projekt ten urósł do ogólnokrajowego ruchu kulturowego, który zapoczątkował rozkwit chińskiej florystyki jako nowej osobnej dyscypliny, a w kręgu jej zainteresowań znalazły się ludowe opowieści, poezja, taniec czy lalkarstwo.

Kwestia ratowania niematerialnej części kultury chińskiej przed wpływami zachodnimi i globalizacja przybrała ponownie na intensywności na początku lat 80 . XX wieku jako odpowiedź na wdrażanie przez rząd centralny reform Denga Xiaopinga, ukierunkowanych na zmiany i otwarcie kraju na świat. Miały one rewolucyjny charakter - zakładały przede wszystkim modernizację Chin, które z państwa w dużej mierze agrarnego i „upadłego” miało stać się industrialna potęga, z czym wiązał się ogromny skok gospodarczy i technologiczny. Ponadto reformy kładły nacisk na okcydentalizację Chin, ich otwarcie na współpracę międzynarodową i kulturę zachodnią.

W związku z rosnącym niepokojem i niezadowoleniem wśród chińskiej społeczności akademickiej przedstawiciele ruchu folklorowego podjęli próby wywarcia presji na władzy, aby zaprzestała działań destrukcyjnych dla kultury. W odpowiedzi chińskie Ministerstwo Kultury wraz z Państwową Komisją ds. Etnicznych oraz Chińską Federacją Środowisk Literackich i Artystycznych (CFLAC) wspólnie zainicjowały stworzenie Driesiecin zbiorów literatury i sztuki etnicznej i ludowej Chin ${ }^{28}$. Zawarto w nich ludowe pieśni, przysłowia, opowieści, legendy, formy i style taneczne, chińską muzykę operowa, arie i inne istotne elementy kultury, które przez lata stanowiły fundament chińskiej tożsamości. Osoby odpowiedzialne za poszczególne elementy składowe zbiorów odwiedzały chińskie wioski w celu zbierania fragmentów ludowej tradycji, aby potem stworzyć zestawienia dla każdego powiatu, z podziałem na gatunki, z których w efekcie powstały obszerne tomy z opisem niematerialnego dziedzictwa kultury Chin. Dzięki temu odżyło wiele gatunków lokalnego folkloru, które na przestrzeni minionych lat straciły na znaczeniu i zaczęły zanikać. Do 2004 r. powstało aż 298 tomów, zawierających opis tradycji charakterystycznych dla poszczególnych prowincji, które zostały opublikowane w 2009 r., zyskując miano „Wielkiego Muru kultury”29. Co więcej, za sprawą Ruchu na rzecz Ochrony Niematerialnego Dziedzictwa Kulturowego rząd chiński ustanowił drugą sobotę czerwca Dniem Ochrony Dziedzictwa Kultury. Tego dnia propaguje się elementy

\footnotetext{
27 An Deming, Ochrona niematerialnego dziedzictwa kulturowego: globalna kampania i jej realizacja w Chinach [w:] Niematerialne dziedzictwo kulturowe: doswiadczenia w ochronie krajów Europy Środkowej i W schodniej oraz. Z. Chin. 10-lecie wejscia w ṡycie Konwencji UNESCO ₹.2003 roku w perspek.tywie zrównoważonego rozwoju, red. H. Schreiber, Warszawa 2017, s. 55.

28 Ibidem.

${ }^{29}$ Ibidem, s. 56, 57.
} 
kultury ludowej Chin, w szczególności wśród młodego pokolenia, aby zachęcić ich do kultywowania tradycji.

Ruch na rzecz Ochrony Niematerialnego Dziedzictwa Kulturowego w Chinach niewatpliwie stworzył podwaliny dla współczesnych społecznych form rozwoju i ochrony niematerialnej spuścizny chińskiej kultury. Dzięki angażowaniu zarówno obywateli, jak i instytucji różnego szczebla, z różnych regionów Chin Ruch ten uzyskał rangę ogólnokrajowa, zyskując wsparcie nie tylko chińskiego rządu, ale również organizacji międzynarodowych, w tym przede wszystkim UNESCO, w promowaniu i rozpowszechnianiu chińskiego folkloru. W 2014 r. podczas posiedzenia Międzynarodowego Komitetu ds. Ochrony Niematerialnego Dziedzictwa Kulturowego UNESCO w Paryżu podjęto decyzję o utworzeniu Zespołu Ewaluacyjnego, którego zadaniem będzie ocena wniosków do uzyskania wpisu na listy UNESCO. W skład pierwszego Zespołu Ewaluacyjnego na 3 lata weszło Chińskie Towarzystwo Sztuki Ludowej, co umożliwiło przedstawicielom chińskiego folkloru działanie na rzecz ochrony niematerialnego dziedzictwa kultury również na szczeblu międzynarodowym $^{30}$. Bezpośrednia styczność działaczy ze strukturą UNESCO i praktyką innych państw członkowskich sprawiła, że Chińskie Towarzystwo Sztuki Ludowej podjęło działania, aby wprowadzić zintegrowaną ochronę dziedzictwa niematerialnego, ze szczególnym uwzględnieniem folkloru i tradycji.

W efekcie rząd chiński i UNESCO na podstawie porozumienia współpracują ze sobą i budują wspólną strategię dotyczącą kultury tradycyjnej. Priorytetem w wyznaczaniu celów było przede wszystkim zachowanie autentyczności określonych elementów oraz postawienie linii granicznej pomiędzy czystością tradycji a jej sztucznością rozwijaną na potrzeby turystyki i komercjalizacji. Niematerialne dziedzictwo kultury jest jednak bardzo podatne na przekształcenia i poprzez przekazywanie z pokolenia na pokolenie niejednokrotnie zmienia swoja pierwotna postać. Upływ czasu i zmiany przestrzenne, w tym liczne migracje, a także wchłanianie elementów innych kultur mają znaczący wpływ na obecny kształt kultury tradycyjnej. Dlatego też ostatecznie porzucono dążenie do ochrony autentyczności tradycji, gdyż uznano to działanie za niemożliwe do wykonania w świetle wymienionych czynników, a skupiono się na zintegrowaniu ochrony całego niematerialnego dziedzictwa kultury ${ }^{31}$.

W procesie integracji niewątpliwie duże znaczenie miała realizacja celów i założeń konwencyjnych w ramach członkostwa Chin w UNESCO. Konwencja UNESCO z 2003 r. nałożyła na państwa-strony liczne obowiązki, w tym przede wszystkim obowiązek podjęcia środków ochrony dziedzictwa na szczeblu krajowym. Należą do nich: wprowadzenie odpowiednich regulacji prawnych, prowadzenie list i rejestrów elementów niematerialnego dziedzictwa kultury, zapewnienie specjalnej organizacji

30 Ibidem, s. 61.

31 Ibidem, s. 63. 
administracyjnej (w tym organów odpowiedzialnych za ochronę) oraz inicjowanie i wspieranie akcji społecznych mających na celu propagowanie tego dziedzictwa ${ }^{32}$.

Wraz z przystappieniem do konwencji UNESCO z 2003 r. Chiny rozpoczęły wdrażanie jej postanowień, ustanawiając specjalny centralny organizm administracyjny, odpowiedzialny za sprawy związane z ochroną kultury ludowej, w skład którego weszli eksperci z każdej dziedziny kultury. W 2006 r. oficjalnie przekształcił się on w Chińskie Centrum Ochrony Niematerialnego Dziedzictwa Kulturowego, które stało się głównym organem odpowiedzialnym za sprawy związane z ochroną i rozwojem chińskiej kultury niematerialnej. Zadania Chińskiego Narodowego Centrum są również realizowane na szczeblu lokalnym przez specjalnie utworzone instytucje, odpowiedzialne za wdrażanie środków ochrony w określonych społecznościach. Ministerstwo Kultury, w ramach działania Centrum i realizacji postulatów ruchu folklorystycznego, rozpoczęło pierwsze krajowe badanie niematerialnego dziedzictwa kultury, które trwało do 2009 r. i obejmowało prawie 500 tys. osad i ponad milion wizyt u twórców ludowych. Oprócz tego badania zgromadziły zbiór 290 tys. cennych artefaktów i dokumentów, prawie 2 mld spisanych słów, 230 tys. godzin nagrań zdjęciowych, ponad 4,5 mln zrobionych zdjęć i były pierwszym tak obszernym zbiorem niematerialnego dziedzictwa kultury w Chinach $^{33}$.

W 2006 r. weszły w życie Tymczasowe środki w zakresie ochrony niematerialnego dziedzictwa kultury ${ }^{34}$, czyli pierwsza krajowa regulacja prawna dotycząca ochrony kultury niematerialnej, przygotowana przez Ministerstwo Kultury ChRL. Wskazane w tym dokumencie środki zostały opracowane z myślą o zapewnieniu możliwie najskuteczniejszej ochrony niematerialnemu dziedzictwu kultury, a także usprawnieniu prac administracyjnych w stosunku do elementów chronionych i stworzenia mechanizmów, które pozwolą na ich przekazywanie, a tym samym zachowanie. W myśl art. 3 tego dokumentu działalność na rzecz narodowego niematerialnego dziedzictwa kultury powinna uwzględniać pierwszeństwo ochrony i ratowania zagrożonych dóbr, ich rozwój i zapewnienie trwałości, przy jednoczesnym poszanowaniu ich integralności oraz autentyczności. W dalszej części podkreślono rolę Rady Państwa w przygotowaniu planu ochrony państwowego niematerialnego dziedzictwa kultury oraz jego sukcesywnej realizacji, w tym przede wszystkim za pośrednictwem odpowiednich departamentów na szczeblu lokalnym. Zwrócono też uwagę na potrzebę utworzenia instytucji, które będą zbierać, rejestrować oraz archiwizować określone

32 Zob. S. Kowalska, Legal Protection of the Intangible Cultural Heritage, „Societas et Iurisprudentia" 2014, vol. II, issue 3, s. 79-95.

33 Okresowe sprawozdanie Chińskiej Republiki Ludowej dotyczące realizacji założeń Konwencji w sprawie ochrony niematerialnego dziedzictwa kulturowego, nadesłane 15 grudnia 2010 r., https://ich.unesco.org/en-state/china-CN?info=periodic-reporting (dostęp: 12.04.2020).

34 The Interim Measures for the Protection and Administration of National Intangible Cultural Heritages, http://www.lawinfochina.com/display.aspx?lib=law\&id=5940\&CGid= (dostęp: 25.04.2020). 
elementy, a także zapewnią należyte warunki do zapewnienia im sukcesji i aktywnego rozwoju $\mathrm{u}^{35}$.

Regulacja doprowadziła do wypracowania w środowisku eksperckim i naukowym koncepcji tzw. live transmission, która, co prawda, nie chroni autentyczności, ale zapewnia dziedzictwu dynamiczną ochronę - ochronę na rzecz rozwoju ${ }^{36}$. W przeciwieństwie do utrwalenia elementów dziedzictwa niematerialnego za pomocą tekstu oraz rejestracji dźwięku i obrazu, live transmission zakłada ich utrwalenie za pomoca żywej istoty - drugiej osoby, czyli jest to proces interaktywny, w którym uczestniczy nadawca czynności i jej odbiorca ${ }^{37}$. Takie rozwiązanie z pewnością jest bardziej efektywne, ponieważ łatwiej zachować i rozwinąć dany fragment tradycji, gdy bezpośrednio w jego naukę zaangażuje się drugiego człowieka, który później będzie mógł zdobytą wiedzę przekazać dalej.

Oprócz tego rok 2006 zaowocował również sporządzeniem na szczeblu krajowym spisu elementów niematerialnego dziedzictwa kultury, z podziałem na prowincje, regiony autonomiczne (np. Tybet) oraz specjalne regiony administracyjne (np. Hongkong). Wraz z jego sporządzeniem Ministerstwo Kultury wypracowało sześć kryteriów, jakie musi spełnić dany element, aby został uwzględniony na liście. Zatem: 1) musi mieć wyjątkową wartość i prezentować kreatywność chińskiej cywilizacji; 2) musi być zakorzeniony w chińskiej tradycji kultury danej społeczności i być przekazywany z pokolenia na pokolenie (jest to nawiązanie do konwencji UNESCO z 2003 r., która również zwraca uwagę na znaczenie dla społeczeństwa chronionych elementów); 3) powinien pomóc w promowaniu chińskiej identyfikacji narodowej oraz wzmacniać solidarność i tożsamość narodowa; 4) powinien prezentować niezwykły poziom kunsztu i umiejętności; 5) powinien wykazywać wyjątkową wartość narodowych tradycji kulturowych Chin oraz 6) podkreślać istotność przekazywania chińskiej kultury narodowej w obliczu poważnego zagrożenia zaniknięciem, spowodowanego transformacjami społecznymi lub brakiem środków ochronnych ${ }^{38}$.

Tymczasowe środki w zakresie ochrony niematerialnego dziedzictwa kultury wprowadzone w 2006 r. i uzupełniane przez Ministerstwo Kultury przez kolejne lata doprowadziły finalnie do uchwalenia w 2011 r. Prawa Chińskiej Republiki Ludowej o niematerialnym dziedzictwie kulturowym. Ustawa ta przyspieszyła rozwój ochrony niematerialnego dziedzictwa kultury w Chinach i podniosła poziom wiedzy społeczeństwa na ten temat. Zwiększyła też ogólny wpływ Chin na świecie realizowała bowiem nie tylko ogólne założenia konwencji UNESCO z 2003 r., ale

35 Ibidem, art. 8, http://www.lawinfochina.com/display.aspx?lib=law\&id=5940\&CGid= (dostęp: 13.04.2020).

${ }^{36}$ X. Song, Y. Yang, R. Yang, M. Shafi, Keeping Watch on Intangible Cultural Heritage: Live Transmission and Sustainable Development of Chinese Lacquer Art, „Sustainability” 2019, vol. 11, s. 3.

37 Ibidem.

38 Okresowe sprawozdanie Chińskiej Republiki Ludowej dotyczące realizacji założeń Konwencjiw sprawie ochrony niematerialnego dziedzictwa kulturowego, nadesłane 15 grudnia 2010 r. 
również powstała pod wpływem programu tej organizacji pod nazwą Arcydzieła ustnego i niematerialnego dziedzictwa kulturowego ludzkości. Program realizowany był w latach 2001-2005 i poprzez wyróżnianie wybranych zjawisk z zakresu dziedzictwa niematerialnego miał zachęcić państwa do rozwijania systemu ochrony na swoim terytorium ${ }^{39}$.

Artykuł 2 Prawa Chińskiej Republiki Ludowej o niematerialnym dziedzictwie kulturowym (dalej: Prawo) definiuje niematerialne dziedzictwo kultury jako różne tradycyjne przejawy kulturowe, które są przekazywane z pokolenia na pokolenie przez wszystkie narodowości i uważane za nieodłączną część ich dziedzictwa kultury. Zawiera on również katalog przedmiotów fizycznych i obiektów związanych z tradycyjnymi przejawami kultury, w którym wymienia: 1) tradycyjną literaturę ustną oraz język będący jej nośnikiem, 2) tradycyjne sztuki piękne, kaligrafię, muzykę, taniec, sztukę ludową oraz akrobatykę, 3) tradycyjny kunszt, medytację oraz kalendarz, 4) tradycyjne rytuały, festiwale i inne zwyczajne ludowe, 5) tradycyjny sport i rozrywkę oraz 6) inne niematerialne dziedzictwo kultury ${ }^{40}$.

Jednocześnie ustawa wprowadziła środki, które mogą służyć efektywniejszej ochronie elementów niematerialnego dziedzictwa kultury, takie jak ich afirmacja, nagrywanie i archiwizacja. Tak jak w przypadku Tymczasowych środków w zakresie ochrony niematerialnego dziedzictwa kultury, również tutaj ustawodawca kładzie nacisk na zachowanie autentyczności, integralności i trwałości niematerialnego dziedzictwa kultury, co ma sprzyjać jedności narodu i promowaniu społecznej harmonii oraz zrównoważonego rozwoju kulturalnego (art. 4 Prawa). Podkreślono również rolę rządowych departamentów, zarówno na szczeblu centralnym, jak i regionalnym, w poszukiwaniu, a następnie w rozpoznawaniu elementów niematerialnego dziedzictwa kultury i podejmowaniu adekwatnych kroków w celu zapewnienia im odpowiedniej ochrony. $\mathrm{Na}$ mocy art. 18 Prawa oficjalnie również powierzono Radzie Państwa ustanowienie katalogu reprezentacyjnych pozycji niematerialnego dziedzictwa kultury na poziomie krajowym, składających się z elementów, które odzwierciedlają wybitną kulturę tradycyjną narodu chińskiego i mają wyjątkową wartość historyczna, literacka, artystyczną lub naukową, którą należy chronić i rozwijać. Ustawa taki katalog przewiduje również dla lokalnego niematerialnego dziedzictwa kultury, za którego sporządzenie odpowiedzialne są samorządy prowincji, regionów autonomicznych oraz gmin, a podlegające bezpośrednio władzy centralnej. Jak można więc zauważyć, wprowadzony przez Prawo Chińskiej Republiki Ludowej

\footnotetext{
39 H. Schreiber, Driesięć spostrzèzeń z. okeazji 10-lecia wejścia w życie Konwencji UNESCO w sprawie ochrony niematerialnego dziedzictwa kulturowego ₹.2003 roku [w:] Niematerialne dziedzictwo kulturowe..., s. 481.

40 Law of the People's Republic of China on Intangible Cultural Heritage entered into force 25 February 2011, https://urbanlex.unhabitat.org/sites/default/files/urbanlex//intangible_cultural_heritage_law_of_the_peoples_republic_of_china_2011.pdf (dostęp: 11.04.2020).
} 
o niematerialnym dziedzictwie kulturowym państwowy system ochrony ma charakter scentralizowany.

Ustawa ta zapewniła solidną gwarancję dla wdrożenia i skutecznego działania 12. Planu Pięcioletniego ochrony niematerialnego dziedzictwa kultury na lata 20112015, przyjętego przez Narodowy Kongres Ludowy 14 marca 2011 r. W czasie jego realizacji dziewiętnaście regionów sukcesywnie wprowadziło lokalne przepisy dotyczące niematerialnego dziedzictwa kultury. Bardzo ważnym krokiem w ramach planu było również stworzenie specjalnego funduszu na rzecz ochrony niematerialnego dziedzictwa kultury, który miał wspierać krajowe elementy kultury tradycyjnej. Zgromadzone środki są przeznaczane na wszelkie działania związane z przedmiotowa ochroną i zarządzaniem - przede wszystkim sporządzanie planów i przeprowadzanie badań, promowanie elementów kultury tradycyjnej i ich publikowanie (np. w przypadku niespisanych form literatury ustnej), a także archiwizowanie i tworzenie baz danych. Komisja Rozwoju i Reform opracowała również odpowiednie plany i programy, które miały na celu budowę obiektów służących do zabezpieczenia i zachowania elementów najbardziej narażonych na zanikanie ${ }^{41}$. W ten sposób do tej pory udało się dzięki funduszowi stworzyć osiem krajowych stref ochronnych, w skład których weszły obszary szczególnie bogate w źródła niematerialnego dziedzictwa kultury, wdrożono projekt rewitalizacji tradycyjnego rzemiosła, czego efektem jest przywrócenie do działania prawie 73 tradycyjnych rzemiosł oraz utworzono listę stu krajowych produktów niematerialnego dziedzictwa kultury ${ }^{42}$. Dodatkowo udało się zainicjować studia i szkolenia z zakresu chińskiej niematerialnej spuścizny kultury, wprowadzane sukcesywnie w instytucjach szkolnictwa wyższego, w szczególności tych, które posiadają już elementy tego dziedzictwa, np. na Uniwersytecie Zhejiang.

Minęło 16 lat od momentu, kiedy Chiny przystapiły do Konwencji UNESCO w sprawie ochrony niematerialnego dziedzictwa kultury, a Państwo Środka nie zwalnia tempa w zapewnianiu mu ochrony zgodnie z duchem konwencji. Obecnie duży nacisk kładzie się na rozwój środków ochrony na szczeblu lokalnym. To właśnie samorządy na poziomie prowincji, gmin i regionów są głównie odpowiedzialne za poszukiwanie i identyfikację niematerialnego dziedzictwa kultury oraz zarządzanie nim, jednocześnie kierując się przy tym wartościami wytyczonymi przez rząd. Zmieniono również podejście do elementów niematerialnego dziedzictwa kultury - priorytetem nie jest już samo ich podtrzymanie, ale danie mu „drugiego życia”. Wspomniane wcześniej odejście od dążenia do zachowania ,,autentyczności” dziedzictwa pozwoliło na jego ewoluowanie. Tradycyjne rzemiosło nie jest już zamknięte w kategorii konserwatorskiej i zamrożone w czasie, ale odpowiada potrzebom ludności, staje

${ }^{41}$ Okresowe sprawozdanie Chińskiej Republiki Ludowej dotyczące realizacji założeń Konwencji w sprawie ochrony niematerialnego dziedzictwa kulturowego nadesłane 15 grudnia $2017 \mathrm{r}$., https://ich.unesco.org/en-state/china-CN?info=periodic-reporting (dostęp: 12.04.2020).

42 Ibidem. 
się bardziej praktyczne, przy jednoczesnym zachowaniu swojej identyfikacji z daną grupa etniczna. W Chongzhou fabryka tkactwa Jijun produkuje tradycyjne kosze z bambusa z charakterystycznym dla nich wzorem, a dzięki współpracy z Chińską Akademią Sztuk Pięknych i uniwersytetem w prowincji Sichua, która zapoznała młodych projektantów z praca $\mathrm{z}$ tradycyjnym materiałem, fabryka urozmaiciła swoje wyroby o nowe projekty, w których tradycja połączyła się ze współczesnością. W ten sposób powstaja już nie tylko kosze, ale również torebki, meble i dekoracje do domu, wszystkie wykonane $z$ bambusa i posiadające tradycyjne elementy ${ }^{43}$. Dowodzi to, że Chiny cały czas poszukują nowych sposobów na zapewnienie odpowiedniej ochrony niematerialnemu dziedzictwu kultury, w szczególności takich, które sprostają warunkom stworzonym przez postępująca globalizację i komercjalizację.

\section{Podsumowanie}

Temat ochrony niematerialnego dziedzictwa kultury jest wciąż żywy i aktualny. Można nawet stwierdzić, że wraz z postępująca globalizacją $i$ industrializacją rośnie potrzeba zapewnienia jak najbardziej efektywnego systemu ochrony elementom kultury tradycyjnej, które są w dużym stopniu narażone na negatywne skutki obu zjawisk.

Oprócz form ochronnych, które oferuje społeczność międzynarodowa, w tym przede wszystkim UNESCO, państwa muszą same zadbać o środki mogące zapewnić kulturze przetrwanie, w szczególności poprzez wprowadzanie odpowiednich aktów prawnych. Chińska Republika Ludowa, jako państwo mocno uprzemysłowione i prężnie rozwijające się gospodarczo, a jednocześnie posiadające ogromne bogactwo dziedzictwa kultury, jest w szczególności wymieniana wśród krajów, które muszą w swojej polityce kłaść nacisk na ochronę i rozwój niematerialnego dziedzictwa kultury.

Chińska Republika Ludowa rzetelnie realizuje środki ochrony niematerialnego dziedzictwa kultury wprowadzone przez konwencję UNESCO z 2003 r. Przede wszystkim ustanowiono prawną regulację tej ochrony, która spowodowała wypracowanie spójnego mechanizmu ochronnego i dała podstawy do tworzenia jego kolejnych elementów, takich jak fundusz na rzecz ochrony niematerialnego dziedzictwa kultury. Stworzono jednolity aparat administracyjny dla zarządzania środkami ochrony, działający na szczeblu krajowym oraz lokalnym. Podkreślono w ten sposób rolę samorządów prowincji, gmin i regionów autonomicznych jako pierwszego ogniwa w poszukiwaniu elementów niematerialnego dziedzictwa kultury i w udzielaniu im ochrony w celu zapewnienia ich trwałości oraz w największym możliwym

${ }^{43} \mathrm{~N}$. Thomas, Working with Intangible Culture Heritage in China, https://medium.com/making-as-national-transformation/working-with-intangible-culture-heritage-in-china-8fce $4 \mathrm{f} 178 \mathrm{~d} 1$ (dostęp: 14.04.2020). 
stopniu również niezmienności i autentyczności. W ten sposób Chiny realizują podstawowe wartości, dostosowując się do standardów międzynarodowych.

Oprócz tego w dalszym ciagu prężnie działa Ruch na rzecz Niematerialnego Dziedzictwa Kulturowego, skupiając się na aktywizacji młodych ludzi w celu praktykowania chińskich tradycji. Niewątpliwie najważniejszym czynnikiem umożliwiającym kulturze tradycyjnej przetrwanie jest społeczeństwo. To dzięki kultywowaniu tradycji i przekazywaniu jej z pokolenia na pokolenie kreuje się jej trwałość i ciągłość. Współcześni młodzi Chińczycy są dalecy od praktykowania tego, co dla ich dziadków i pradziadków było elementem życia codziennego. Wpływy zachodnie i media społecznościowe prawie całkowicie pozbawiły ich tożsamości kulturowejtej narodowej lub etnicznej, co powoduje zanik tradycyjnych form kultury. Dlatego tak ważne jest rozpowszechnianie i promowanie przez państwo programów społecznych, które za cel obrały sobie rozwój dziedzictwa kultury, przede wszystkim tego niematerialnego, i zachęcają do powrotu do korzeni, bo to one mają największy wpływ na współczesne społeczeństwo. Znaczy to, że Chińska Republika Ludowa pomimo ogromu pracy, jaką wkłada w ochronę i rozwój niematerialnego dziedzictwa kultury, wciąż musi szukać nowych metod i środków, które pozwolą uchronić to, co było kształtowanie przez setki, a nawet tysiące lat chińskiej historii.

\section{SUMMARY}

\section{MEASURES FOR PROTECTION OF INTANGIBLE CULTURAL HERITAGE IN THE PEOPLE'S REPUBLIC OF CHINA}

The People's Republic of China is currently a country with a dynamically developing economy and strongly progressing globalization. Both phenomena have a negative impact on the preservation and transfer of goods belonging to China's cultural heritage, in particular the intangible, which is considered to be more fleeting. Folklore and tradition require the development of a special protection system, primarily legal, which will ensure an effective protective mechanism. Actions taken by the Chinese government, in cooperation with UNESCO, have undoubtedly saved many elements of China's intangible cultural heritage, but still, in the face of changes, traditional Chinese culture is under threat and requires new activities, including those that will engage society in cultivating China's tradition. 